\title{
Vaccine Candidates for the Control and Prevention of the Sexually Transmitted Disease Gonorrhea
}

\author{
Ethan C. Haese $\mathbb{D}$, Van C. Thai $\mathbb{D}$ and Charlene M. Kahler* \\ Marshall Centre for Infectious Disease Research and Training, School of Biomedical Sciences, University of \\ Western Australia, Crawley, WA 6009, Australia; ethan.haese@research.uwa.edu.au (E.C.H.); \\ vanchi.thai@research.uwa.edu.au (V.C.T.) \\ * Correspondence: charlene.kahler@uwa.edu.au
}

check for

updates

Citation: Haese, E.C.; Thai, V.C.; Kahler, C.M. Vaccine Candidates for the Control and Prevention of the Sexually Transmitted Disease Gonorrhea. Vaccines 2021, 9, 804. https://doi.org/10.3390/ vaccines 9070804

\section{Academic Editors:}

Mariusz Skwarczynski and Istvan Toth

Received: 28 May 2021

Accepted: 17 July 2021

Published: 20 July 2021

Publisher's Note: MDPI stays neutral with regard to jurisdictional claims in published maps and institutional affiliations.

Copyright: (c) 2021 by the authors. Licensee MDPI, Basel, Switzerland. This article is an open access article distributed under the terms and conditions of the Creative Commons Attribution (CC BY) license (https:// creativecommons.org/licenses/by/ $4.0 /)$.

\begin{abstract}
The World Health Organization (WHO) has placed N. gonorrhoeae on the global priority list of antimicrobial resistant pathogens and is urgently seeking the development of new intervention strategies. N. gonorrhoeae causes 86.9 million cases globally per annum. The effects of gonococcal disease are seen predominantly in women and children and especially in the Australian Indigenous community. While economic modelling suggests that this infection alone may directly cost the USA health care system USD 11.0-20.6 billion, indirect costs associated with adverse disease and pregnancy outcomes, disease prevention, and productivity loss, mean that the overall effect of the disease is far greater still. In this review, we summate the current progress towards the development of a gonorrhea vaccine and describe the clinical trials being undertaken in Australia to assess the efficacy of the current formulation of Bexsero ${ }^{\circledR}$ in controlling disease.
\end{abstract}

Keywords: Neisseria gonorrhoeae; gonorrhea; vaccine development; antimicrobial resistance; multidrug resistance; sexually transmitted infections

\section{Introduction}

Gonorrhea is a sexually transmitted infection (STI) caused by the Gram-negative bacteria Neisseria gonorrhoeae (also called gonococcus). There were an estimated 376 million new cases of curable STIs (chlamydia, gonorrhea, syphilis, and trichomoniasis) in 2016, 86.9 million of which were cases of gonorrhea [1]. STIs result in a substantial economic burden on individuals and society. Low-to-middle income countries often have higher estimated burdens of disease than high-income countries. Recent models indicate that subSaharan Africa and the Western/Eastern Pacific regions bear a disproportionate burden of $75 \%$ of global STI control costs [2]. Modelling of total costs are divided into two categories - direct medical costs for screening diagnostic tests and treatments, and lifetime costs associated with infertility which result in the need to access assisted reproductive techniques [3] and low-birth weight/preterm birth complications [4] which result in a high cost burden on public health systems.

Mathematical models based on 2008 data from the United States of America (USA) estimated a total lifetime direct medical cost for STIs of USD 15.6 (range: USD 11.0-20.6) billion (adjusted to the USD in 2010) [5]. The estimated direct medical costs of gonorrhea infections specifically were approximately USD 162.1 (range: USD 81.1-243.2) million [5]. Another model estimated that the emergence of antimicrobial resistant (AMR) N. gonorrhoeae could lead to 1.2 million more gonococcal infections over 10 years in the USA alone, costing an additional USD 378.2 million [6]. However, these estimates still do not reflect the true economic burden of $N$. gonorrhoeae infections as they exclude the indirect and intangible costs associated with adverse disease and pregnancy outcomes, disease prevention, and productivity loss [3].

Effective antimicrobial treatment is essential for the prevention and control of N. gonorrhoeae infections, and the increased emergence of multidrug resistant (MDR) and extensively 
drug resistant (XDR) N. gonorrhoeae strains has heightened concern about the possibility of widespread untreatable gonorrhea [7]. The World Health Organization (WHO) has highlighted the urgent need for the development of new antibiotic and antivirulence treatment options and vaccines for the sustainable control of future untreatable N. gonorrhoeae infections [8]. The WHO and the National Institute of Allergy and Infectious Diseases (NIAID) initiated the Global Roadmap for Advancing Development of Vaccines Against STIs, which outlines the important action steps needed to advance vaccine development for STIs, including gonorrhea [9-12]. The key priority action areas from the roadmap include: (1) obtaining better epidemiological data; (2) modelling theoretical vaccine impact and cost-effectiveness; (3) advancing basic science and translational data in clinical trials; (4) defining preferred product characteristics for first-generation vaccines; and (5) characterizing the public health value of vaccines to encourage investment and guide policy decisions [11] (see [10,13] for a full review and report).

Interest in vaccine development against $N$. gonorrhoeae has been revived recently by both the increased global interest in the use of vaccines to fight AMR bacteria $[9,14]$ and observational studies reporting that vaccines developed against the closely related pathogen Neisseria meningitidis (also called meningococcus) serogroup B (MenB) might provide moderate protection against gonorrhea [15-17]. While these studies provide promise that vaccines against $N$. gonorrhoeae are biologically feasible, they also reinforce the need to characterize the full immune response in mice and for human clinical trials to determine the efficacy of vaccine antigens.

\section{N. gonorrhoeae Infection and Disease}

N. gonorrhoeae typically colonizes the urogenital mucosa, but can also colonize extragenital mucosal sites, including the rectal or oropharyngeal mucosal epithelia (Figure 1). N. gonorrhoeae is easily transmitted, with a substantial proportion of individuals becoming infected after a single exposure. The estimated probability of penile-to-vaginal or vaginal-to-penile transmission is approximately $50 \%$ and $20 \%$ per sex act, respectively [18]. Estimated probabilities of transmission among gay and bisexual men or men who have sex with men (MSM) during oral and anal sex are much higher than heterosexual men, at 63\% for urethral-to-pharyngeal transmission and 84\% for urethral-to-rectal transmission [19].

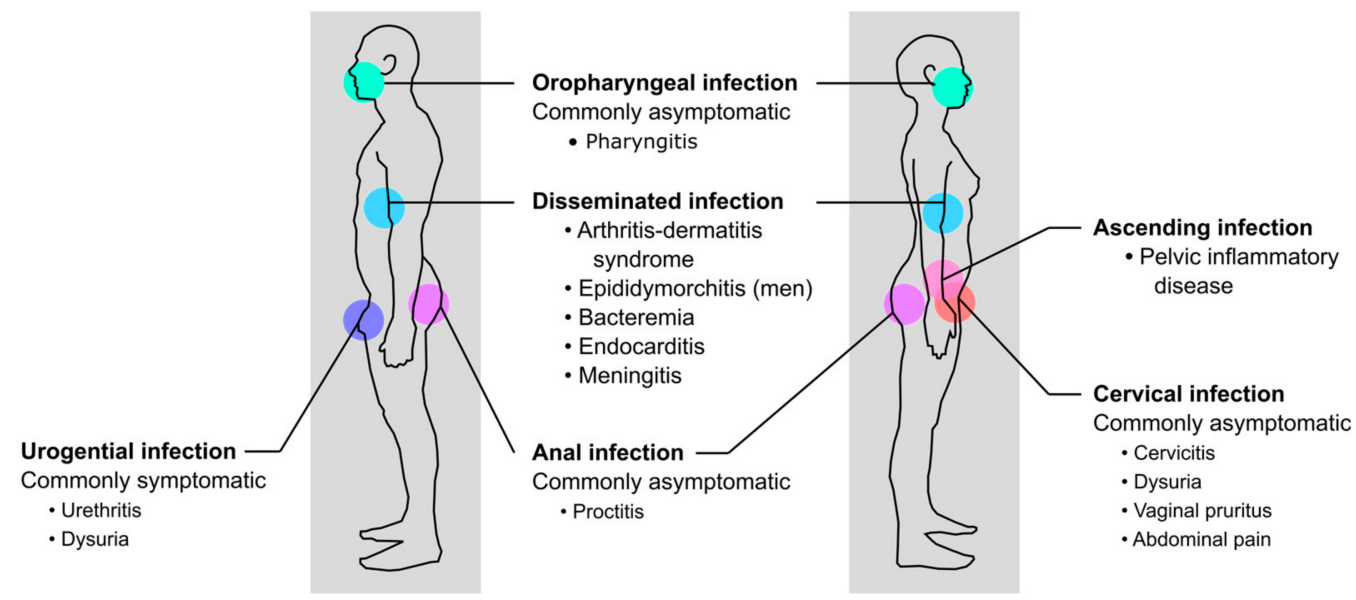

Figure 1. Site of infection and clinical symptoms of gonorrhea in men and women.

Lower genital tract infections in men are commonly symptomatic, presenting as uncomplicated urethritis with urethral discharge of a purulent exudate and dysuria after an average incubation period of one week for heterosexual men [20,21] and four days for MSM [22]. However, for some men, clinical presentations may occur as early as 1-2 days after the last sexual contact $[23,24]$. Among women, genital tract infections are primarily asymptomatic or minimally symptomatic, often going unrecognized or misdiagnosed as other reproductive tract infections. When present, genital symptoms develop in most 
women within 10 days of exposure, manifesting as acute cervicitis with mucopurulent discharge, dysuria, vaginal pruritus, or abdominal pain $[25,26]$. Among both sexes, rectal and oropharyngeal infections are usually asymptomatic but can present symptomatically as proctitis and pharyngitis, respectively [27].

Without treatment more invasive forms of disease can occur, including epididymoorchitis in men and pelvic inflammatory disease (PID) in women, or disseminated gonococcal infection with bacteremia in both sexes [28]. Most N. gonorrhoeae strains that disseminate do not cause urethritis, but infection of a mucosal site usually precedes cases of disseminated disease [29]. Although uncommon, disseminated disease can cause arthritisdermatitis syndrome [30] and in rare cases endocarditis or meningitis [31-34]. Infection with $N$. gonorrhoeae can also facilitate transmission or acquisition of the human immunodeficiency virus type 1 (HIV-1) [35-39], and infection with N. gonorrhoeae has been reported to repress HIV-1 replication in macrophages inducing a state similar to viral latency [40].

PID is a common and severe complication of ascending infection of the female reproductive tract [41]. If left untreated, PID can cause scarring and dysfunction of the upper genital tract, resulting in chronic pelvic pain, ectopic pregnancy, and infertility [42-44]. Women with $N$. gonorrhoeae infections are also more likely to experience premature rupture of membranes, preterm birth, low birth weight, ophthalmia neonatorum (neonatal conjunctivitis), and neonatal and perinatal mortality [45]. PID has also been associated with STIs caused by Chlamydia trachomatis, the causative agent of chlamydia, and coinfection with $N$. gonorrhoeae and C. trachomatis occurs frequently [46]. However, PID caused by gonococcal infections typically presents with more severe symptoms [47].

\section{Epidemiology of N. gonorrhoeae Infection and Disease in Australia}

There were an estimated 86.9 million (95\% uncertainty interval, UI: 58.6-123.4 million) new global incident cases of urogenital gonococcal infections in 2016, with an incidence rate of 20 per 1000 women (95\% UI: 14-28) and 26 per 1000 men (95\% UI: 15-41) [1]. In most countries, the rates of gonorrhea were often highest among adolescents and young adults, and higher among men than women $[1,18]$. In Australia, there has been a 2.3-fold increase in total gonorrhea notifications and notification rates over the last decade, up from 10,320 (46.8 per 100,000 population) in 2010 to 34,265 in 2019 (134.7 per 100,000 population) [48,49]. While increased testing is a likely factor contributing to increased notification, surveillance data suggest there is an increasing incidence of gonorrhea among heterosexual men and MSM. Notification rates in women have also increased almost 2-fold in the last decade, raising concerns about potential reproductive tract complications from asymptomatic or minimally symptomatic infections [50,51]. Additionally, the prevalence and incidence of gonococcal infections are several-fold higher among marginalized minority populations, particularly sex workers, gay, bisexual, and other men who have sex with men, trans and gender diverse people, and Aboriginal and Torres Strait Islander (Indigenous) people $[18,48,50-53]$.

The sex workers category includes a diverse population who exchange sexual activity for income, employment, survival, or drugs, and sex workers are at increased risk of acquiring HIV-1 and STIs. While there has been a substantial increase in the incidence of oropharyngeal gonorrhea (from 1.6 to 4.9 per 100 person-year, PY) among female sex workers in Australia between 2009-2015, the incidence of urogenital gonorrhea (from 1.0 to 1.7 per $100 \mathrm{PY}$ ) and rectal gonorrhea (from 0.2 to 0.4 per $100 \mathrm{PY}$ ) has remained relatively stable [54]. After testing for oropharyngeal gonorrhea was introduced in 2017 for all female sex workers attending the Melbourne Sexual Health Centre, the prevalence of oropharyngeal gonorrhea was reported as $2.0 \%$ (95\% confidence interval, CI: 1.6-2.6\%) [55]. The prevalence of HIV-1 remained low and did not change over time. Among the female sex workers that tested positive for gonorrhea, 55\% (95\% CI: 43-67\%) only tested positive in the oropharynx, highlighting the oropharynx as a reservoir for transmission and the need for testing extragenital sites of infection [55]. 
There are very limited data on the prevalence of gonorrhea for male sex workers compared to female sex workers. However, recent studies have estimated that the prevalence of gonorrhea among male sex workers in Australia is between 15.0\% (95\% CI: 12.0-19.2\%) [56] and $10.8 \%$ (95\% CI: 4.4-20.9\%) [57]. The positivity for incident HIV-1 infections among male sex workers is between $0.6 \%$ (95\% CI: $0.1-2.5 \%$ ) and $1.7 \%$ (95\% CI: $0.0-5.0 \%$, with a lower positivity for HIV-1 or gonorrhea among male sex workers who exclusively have sex with women compared to those who have sex with men $[56,57]$.

Among gay, bisexual, and other men who have sex with men the prevalence of gonorrhea is quite high. In Australia, the gonorrhea incidence among MSM increased from 14.1 per 100 PY (95\% CI: $13.2-15.0 \%$ ) in 2010 to 24.6 per 100 PY (95\% CI: $23.9-25.4 \%$ ) in 2017, with the greatest increases in oropharyngeal and rectal gonorrhea infections [58]. In contrast to the increase in the notification rate of gonorrhea, there has been a decline in the HIV-1 notification rate from 4.5 to 4.0 per 100,000 population between 2013-2017 among MSM in Australia. Most of this reduction in HIV incidence can be attributed to the introduction of pre-exposure prophylaxis (PrEP) in 2016 [59].

Trans and gender diverse is a term used to describe a group of individuals whose gender identity or presentation is different from the sex presumed for them at birth [60]. While there are limited data on STIs in the trans and gender diverse population, a health survey by the Kirby Institute reported a total rate of gonorrhea in Australian trans and gender diverse individuals of $6.4 \%$ [53]. Available data suggest a substantial prevalence of gonorrhea among transgender women, particularly at extragenital anatomical sites. The prevalence of gonorrhea among transgender women has increased from $3.1 \%$ to $9.8 \%$ over the past seven years but remained stable for transgender men [61,62].

Comparable to other countries with marginalized Indigenous populations such as the USA and Canada, the Indigenous population in Australia suffers disproportionate rates of STIs. In 2017, the rates of gonorrhea among Indigenous people (627.5 per 100,000 population) were 6.6-fold the rate for the non-Indigenous population, increasing to nearly 30 -fold higher in remote and very remote communities (1442.9 per 100,000 population) [52]. The ratio of male to female notifications were almost equal compared with the number of notifications in the non-Indigenous population, which is higher among men than women [52]. Additionally, nearly three-quarters of cases of gonorrhea were notified from people aged 15-29 years among the Indigenous population compared with half in the non-Indigenous population [52]. The disparities between the two populations are most likely caused by differences in risk behaviors and testing patterns and reduced access to health services [63].

\section{Antimicrobial Resistant N. gonorrhoeae}

Although antibiotics have been successful in containing the prevalence of gonorrhea in the past, $N$. gonorrhoeae has successively gained resistance to all previously used first-line antibiotics to the extent that they are no longer recommended for treatment [64]. The WHO has declared $N$. gonorrhoeae a high-priority pathogen for research and development of new antibiotics because of increasing resistance to the extended-spectrum cephalosporin ceftriaxone, the last remaining option for first-line gonorrhea monotherapy $[7,8,64]$. In Australia, current treatment options rely on the use of ceftriaxone and the broad-spectrum macrolide azithromycin as a single dose [65].

While sporadic treatment failures of oropharyngeal gonorrhea with ceftriaxone monotherapy had been confirmed in the past [66-72], the first treatment failure of oropharyngeal gonorrhea with dual therapy was reported in Japan in 2016 [73]. International spread of MDR ceftriaxone-resistant gonococcal strains has since been confirmed in Japan [74], Denmark [75], the United Kingdom [76,77], France [78], Australia [79], and Canada [80]. The first XDR strain with ceftriaxone resistance and high-level azithromycin resistance was isolated in England and Australia in 2018 [81-83].

Existing interventions are insufficient in controlling gonorrhea and without new antibiotics or other therapeutics, there is a concern that untreatable infections will become more common in the future. To confront this issue, different approaches are being investi- 
gated, including improving antibiotic stewardship, novel drug discovery, antivirulence therapeutic approaches, and gonococcal vaccine development for the sustainable control of future $N$. gonorrhoeae infections $[13,64,84-88]$.

\section{Innate and Adaptive Immune Responses to N. gonorrhoeae Infection}

$N$. gonorrhoeae is a highly adapted human pathogen, as individuals treated for gonorrhea can be repeatedly infected with no development of immunological memory, leading to prolonged symptomatic and asymptomatic infections [89-91]. Symptomatic infection is typically characterized by a purulent discharge composed of bacteria and neutrophil granulocytes. N. gonorrhoeae has evolved to modulate and evade host innate and adaptive immune responses (Figure 2). Experimental investigation is complicated by the fact that humans are the only known natural host. However, with the use of human and murine immortalized cell lines and an estrogen-treated murine infection model, insights into the immune modulation and evasion mechanisms utilized by $N$. gonorrhoeae have been revealed $[92,93]$.

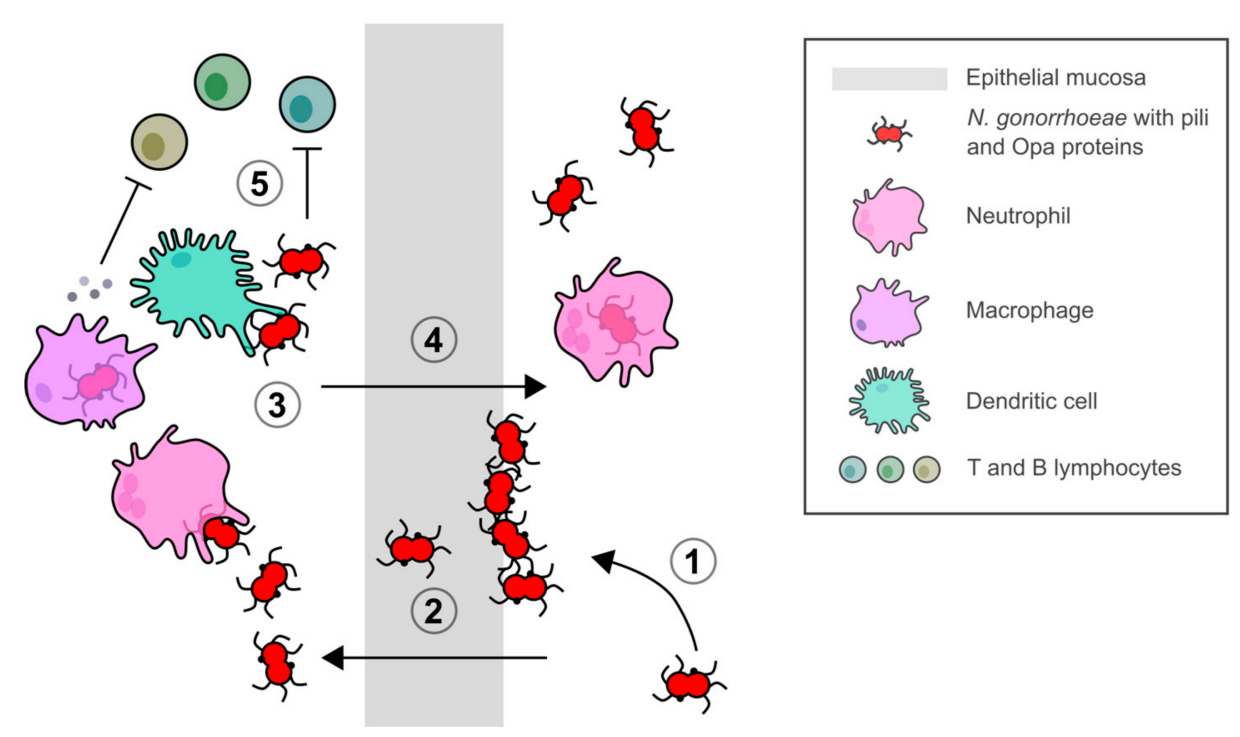

Figure 2. N. gonorrhoeae infection, transmission, and modulation of host immunity. (1) Attachment and colonization of $N$. gonorrhoeae mediated by Type IV pili and Opa proteins. (2) Colonization and invasion of host epithelium and transcytosis through epithelial mucosa. (3) Stimulation of local mucosal immune cells and host inflammatory response. (4) Transmission of bacteria in a neutrophil-rich exudate. (5) Modulation of immune response of $\mathrm{T}$ and B lymphocytes by stimulation of proinflammatory cytokines and chemokines by phagocytic cells to enhance a Th17 immune response and suppress Th1/2 immune responses.

Phase and antigenic variation of major outer membrane surface-exposed Type IV pili and opacity (Opa) proteins [94-96], lipooligosaccharide epitope mimicry [97], and phagosome subversion $[98,99]$ are important mechanisms utilized by $N$. gonorrhoeae to overcome host immune defenses. While gonococcal strains can express up to 10-12 different Opa proteins that differ among strains, Opa52 (also referred to as OpaG) from strain MS11 in particular has been reported to bind to carcinoembryonic antigen-related cellular adhesion molecule 1 (CEACAM-1, CD66a) on activated human CD4+ T lymphocytes and downregulate their activation and proliferation in response to antigens [100,101]. However, Zariri, et al. [102] showed that while Opa-CEACAM-1 binding resulted in reduced Opaspecific antibody titers in a human-CEACAM-1 transgenic mouse model, there was no difference in the immune response against outer membrane vesicles (OMVs) indicating that these antigens may not have an effect on vaccine design. $N$. gonorrhoeae also interacts with local mucosal immune cells to modulate host immune responses. Similarly to Opa, 
the major outer membrane porin PorB inhibits dendritic cell stimulation of CD4+ T cell proliferation [103,104].

Mucosal resident macrophages and recruited neutrophils and monocytes fail to control N. gonorrhoeae replication during an infection [105-107]. N. gonorrhoeae upregulates expression of immunoregulatory cytokines interleukin-1 (IL-1), IL-6, IL-8, IL-10, and tumor necrosis factor alpha (TNF- $\alpha$ ) in human macrophages, which may stimulate inflammatory and immunosuppressive responses [108]. The T cell-stimulating factor IL-12 involved in the Type 1 helper T cell (Th1) response was only detected from challenged macrophages derived from primary human monocytes (MDM) [108]. In addition, infected murine macrophages expressed the immunoregulatory cytokines IL-10 and transforming growth factor beta (TGF- $\beta$ ), but not the proinflammatory cytokine TNF- $\alpha$ [109]. There was also no upregulation of costimulatory CD86 and major histocompatibility complex class II molecules reported, indicating that a tolerogenic phenotype was induced in the antigenpresenting cells [109]. MDM challenged with N. gonorrhoeae have also been reported to differentiate toward an M2 profile [110]. During an infection, macrophages are polarized into classical proinflammatory M1 or alternative anti-inflammatory/proresolving M2 activated macrophages in response to host immune mediators and infectivity or virulence factors [111]. The M1 phenotype promotes a Th1 response and possesses strong microbicidal and tumoricidal activity [112], while the M2 phenotype promotes clearance of infection, dampens inflammation, tissue remodeling, tumor progression, and possesses immunoregulatory functions [113].

During infection, N. gonorrhoeae selectively suppresses Th1 and Th2 responses and enhances a Th17 response, which is involved in the influx of neutrophils and the recruitment of other innate defense mechanisms (Figure 2, [114,115]). The lack of protective immunity reported following an infection with $N$. gonorrhoeae might be related to the induction of a Th17 response. Antibodies against the surface reduction modifiable protein Rmp (previously referred to as protein III) could also interfere with protective immunity as they block the activity of bactericidal antibodies targeting gonococcal surface antigens [116-118].

Given all these mechanisms for immune evasion and modulation, individuals can be repeatedly infected with no development of immunological memory that can prevent natural reinfection. Therefore, it is unsurprising that early vaccine attempts with a killed whole cell vaccine and single antigen pilus and PorB vaccines were unsuccessful [119-124].

\section{Vaccine Development}

Because infection induces a limited and weak immune response which is strain specific, modern approaches to vaccine development aim to develop vaccines containing broadly antigenic components with immunomodulatory adjuvants that both broaden the antibody responses to encompass a greater antigenic diversity while improving priming to infection. There are four current vaccine approaches: (1) meningococcal and gonococcal OMV vaccines that are intrinsic self-adjuvants; (2) purified protein subunit vaccines; (3) mixed OMV and protein subunit vaccines; and (4) immunotherapeutic vaccines that utilize adjuvants to stimulate Th1-specific immune responses (Table 1).

OMVs are naturally secreted vesicles formed from the invagination of the outer membrane during bacterial growth and contain many outer membrane antigens [125]. Since the antigens are embedded in their natural milieu with endotoxin, this retains structure and improves antigenicity without the need of adjuvants. For this reason, OMVs have been used as the platform for the development of many variants of the meningococcal vaccine [126]. However, these OMVs raise the best responses to homologous strains from which they are derived and so supplementation with other proteins has been used to modify them to raise strong heterologous responses. Multi-subunit vaccines containing multiple proteins or conserved proteins may also raise a broadly cross-protective immune response. Immunotherapeutic vaccines aim to stimulate or enhance the adaptive immune response to gonococcal infections using therapeutic and prophylactic strategies. IL-12 is an inflammatory cytokine that stimulates Th- 1 associated immunity and enhances humoral or 
antibody-mediated immunity $[127,128]$. Preclinical studies using local administration of microencapsulated IL-12 have shown an enhancement of Th1-driven protective immunity and protection against reinfection in mice when given either as a treatment for an existing gonococcal infection [129] or as an adjuvant with a gonococcal vaccine [130,131]. Additionally, mice immunized with multi-antigenic peptide $2 \mathrm{C} 7$ epitope mimic combined with the toll-like receptor 4 agonist monophosphoryl lipid A shortened the time of gonococcal carriage in a female murine genital infection model through a Th1-biased immunoglobulin G subclass 2a antibody response [132,133]. The monoclonal antibody $2 \mathrm{C7}$ epitope is a conserved oligosaccharide structure of LOS from N. gonorrhoeae [134]. While carbohydrates are poor immunogens and induce T-cell-independent immune responses, peptide mimics of carbohydrate antigens elicit broader cross-reactive immune responses and are more promising vaccine candidates [132].

Vaccine development for gonorrhea is still currently in the preclinical phase, as vaccine candidates have yet to be used in human clinical trials. Recent reviews have summarized promising antigen targets and current research and development efforts for vaccines against N. gonorrhoeae $[10,13,84,88,93,134-139]$. Promising vaccine candidates are currently being evaluated in murine infection models with different adjuvants and antigen-delivery systems. The evaluation of vaccine candidates has been challenging because no correlates of protection have been identified against $N$. gonorrhoeae in humans. Current preclinical investigations measure vaccine candidate efficacy by bactericidal or opsonophagocytic activity, blocking of target function, antibody surface binding, and coinfection with N. gonorrhoeae in a female murine genital tract infection model $[93,137]$. However, whether host responses in mice will accurately predict vaccine efficacy in humans remains unknown, and while there is a controlled human infection model it is restricted to experimental urethral infection among male volunteers [140]. This is a restriction on de novo vaccine programs since it has been well established that the initial stages of infection in women including the cell types and receptors used are entirely different from males [28].

Table 1. Approaches for vaccines against $N$. gonorrhoeae.

\begin{tabular}{|c|c|c|}
\hline Vaccine Approach & Vaccine Components/Antigens under Investigation ${ }^{1}$ & References \\
\hline $\begin{array}{l}\text { Meningococcal and gonococcal } \\
\text { OMVvaccines }\end{array}$ & $\begin{array}{c}\text { VA-MENGOC-BC }{ }^{\circledR} \\
\text { MeNZB }^{\circledR}: \text { NZ 98/254 OMV (Omp85, FetA, PorA, PorB3, FbpA, RmpM, } \\
\text { OpcA, and NspA) } \\
\text { Formalin-inactivated whole cell microparticles }\end{array}$ & {$[142,143]$} \\
\hline Purified protein subunit vaccines & $\begin{array}{c}\text { AniA, Lst, OmpA, Opa, OpcA, PilC, PilQ, PorB, TbpB, TbpA, TdfJ, NgoФfil } \\
\text { phage particles }\end{array}$ & {$[135,144]$} \\
\hline $\begin{array}{l}\text { Mixed OMV and } \\
\text { protein subunit vaccines }\end{array}$ & $\begin{array}{l}\text { Bexsero }^{\circledR}: \text { MeNZB OMV antigens with additional } \mathrm{fHbp}, \text { NHBA, and } \\
\text { NadA antigens }\end{array}$ & [145] \\
\hline $\begin{array}{l}\text { Immunotherapeutic } \\
\text { vaccines }\end{array}$ & $\begin{array}{c}\text { OMV vaccine with IL-12 adjuvant } \\
\text { 2C7 LOS epitope mimic multi-antigenic peptide vaccine }\end{array}$ & $\begin{array}{l}{[130]} \\
{[132]}\end{array}$ \\
\hline \multicolumn{3}{|c|}{$\begin{array}{l}{ }^{1} \text { Omp85, outer membrane protein assembly factor; FetA, ferric enterobactin receptor; PorA and PorB, outer membrane porin protein; FbpA, } \\
\text { fibronectin binding protein; RmpM, reduction-modifiable protein; OpcA, outer membrane adhesin; NspA, neisserial surface protein; AniA, } \\
\text { anaerobically induced copper-containing nitrite reductase; Lst, lipooligosaccharide-specific } \alpha \text {-2,3-sialyltransferase; OmpA, outer membrane } \\
\text { protein; PilC, Type IV pilus assembly protein; PilQ, Type IV pilus biogenesis and competence protein; TbpA and TbpB, transferrin-binding } \\
\text { protein; TdfJ, outer membrane TonB-dependent transporter protein; fHbp, factor H binding protein; NHBA, neisserial heparin binding } \\
\text { antigen; and NadA, Neisseria adhesin and invasin. }\end{array}$} \\
\hline
\end{tabular}

\subsection{Evidence of a Protective Effect from Serogroup B Meningococcal Vaccines}

Optimism about the feasibility of gonococcal vaccine development has been recently revived because of accumulating observational data related to vaccines developed for preventing disease from MenB. The composition of the meningococcal polysaccharide capsule defines serogroups, with $\mathrm{A}, \mathrm{B}, \mathrm{C}, \mathrm{W}, \mathrm{X}$, and $\mathrm{Y}$ the main cause of invasive meningococcal disease [146]. 
The evidence for a protective effect provided by the meningococcal VA-MENGOC-BC ${ }^{\circledR}$ vaccine (Finlay Institute, Cuba) against $N$. gonorrhoeae was first reported in Cuba after the rapid decline in gonorrhea incidence following a vaccine campaign from 1988-1990 that targeted the highest-risk population (people aged 3 months to 24 years) $[16,147,148]$. The effectiveness of the vaccine against meningococcal disease was estimated to be between 81 and $83 \%$ after two doses, and the coverage for people under 24 years old was 95\% [147]. VAMENGOC-BC is a bivalent vaccine based on proteoliposome OMVs containing more than one hundred proteins from a hypervirulent MenB strain supplemented with meningococcal serogroup C polysaccharide [141,149]. Many conserved proteins between N. meningitidis and $N$. gonorrhoeae have been identified in the OMV component of the vaccine which could induce cross-reactive bactericidal antibodies against heterologous MenB strains and possibly against $N$. gonorrhoeae $[16,147,150,151]$.

The MenB OMV vaccine MeNZB ${ }^{\circledR}$ (Novartis) was introduced to the national immunization program in New Zealand in 2004. The effectiveness of MeNZB was estimated to be $77 \%$ (95\% CI: 62-85\%) after three doses, and the coverage for people under 20 years old was $81 \%$ [152]. MeNZB was successful in controlling the MenB epidemic and the immunization program ended in March 2011. Mathematical modeling indicated that exposure to MeNZB not only prevented meningococcal disease caused by MenB but also had an effectiveness of $31 \%$ against infection with $N$. gonorrhoeae [15]. Moreover, vaccination significantly reduced the risk of hospitalization from gonorrhea [153].

The development of the recombinant protein-based $4 \mathrm{CMenB}\left(\right.$ Bexsero $\left.^{\circledR}, \mathrm{GSK}\right)$ vaccine is one of the more recent advances in the prevention of invasive meningococcal disease [145]. The Bexsero ${ }^{\circledR}$ vaccine contains the MeNZB OMV antigens and three additional recombinant antigens (factor $\mathrm{H}$ binding protein, $\mathrm{fHbp}$; neisserial heparin binding antigen, NHBA; and Neisseria adhesin A, NadA). The vaccine was first licensed in Europe in 2013, and was later introduced to Australia, Canada, and some countries in South America for use in infants from 2 months of age $[145,154]$. Since 2015, Bexsero ${ }^{\circledR}$ has been approved for use in the USA for people aged 10-25 years. However, it has been licensed for use against MenB outbreaks in universities in the USA since December 2013 [154-156]. A study in the UK found that the effectiveness of the Bexsero ${ }^{\circledR}$ vaccine against meningococcal disease was $82.9 \%$ (95\% CI: $24.1-95.2 \%)$ at approximately 6 months after the two-dose schedule [157]. In a retrospective study in the Saguenay-Lac-Saint-Jean region of Quebec, Canada, after a group of individuals from 2 months to 20 years of age were vaccinated in 2014, there was a 59\% decline in gonorrhea notifications among people aged 14-20 years was observed during the postvaccination period, suggesting the cross-protection of Bexsero ${ }^{\circledR}$ against N. gonorrhoeae [158]. The Bexsero ${ }^{\circledR}$ vaccine induced cross-reactive human antibodies to NHBA, with a 34-fold increase between pre- and post-vaccination [159]. Immunization of estrogen-treated mice with Bexsero ${ }^{\circledR}$ significantly accelerated clearance and reduced N. gonorrhoeae bacterial burden compared to the alum or PBS control [17]. Antibodies from immunized mice could also recognize several gonococcal outer membrane proteins, including PilQ, BamA, MtrE, PorB, and Opa [17]. These findings on the cross-protection of MenB vaccines against $N$. gonorrhoeae have supported the feasibility of vaccine development for gonorrhea.

\subsection{Clinical Trials for Efficacy of Meningococcal Vaccines against Gonorrhea in Australia}

There are two current clinical trials in Australia that are investigating the efficacy of the Bexsero ${ }^{\circledR}$ vaccine in preventing gonorrhea in MSM who are at high risk of gonorrhea infection. The 'MenGO' study is a clinical trial sponsored by the Gold Coast Sexual Health Service in Queensland [160]. This is a Phase III randomized controlled trial of the Bexsero ${ }^{\circledR}$ vaccine for the prevention of gonorrhea infection in the MSM (including cis and trans men, trans women, and nonbinary people who have sex with men), comparing the incidence of gonorrhea among vaccinated and unvaccinated participants. The 'GoGoVax' study is a clinical trial sponsored by the Kirby Institute at the University of New South Wales in Sydney with collaborators at Griffith University in Queensland [161]. This is a Phase 
III, double-blinded, randomized placebo-controlled, multicentered trial also evaluating the efficacy of the Bexsero ${ }^{\circledR}$ vaccine in the prevention of gonorrhea in MSM. The primary outcomes of this study are to determine whether the Bexsero ${ }^{\circledR}$ vaccine changes the incidence of the first instance of symptomatic N. gonorrhoeae infection of the urethra, anorectum, or vagina, and the overall incidence of all $N$. gonorrhoeae infections during the study period between vaccinated and unvaccinated participants.

Additionally, the 'B Part of it NT' study is an observational study sponsored by the University of Adelaide with collaborators from universities and government bodies from around Australia [162]. This study will aim to implement a targeted Bexsero ${ }^{\circledR}$ immunization program in adolescents aged 14-19 years in the Northern Territory. While the primary aim of this study is to examine the carriage of N. meningitidis in the nasopharynx, there is a secondary observational arm which will compare the rates of gonorrhea in the vaccinated versus unvaccinated participants. This is an important study as it will directly assess the impact of Bexsero ${ }^{\circledR}$ in Indigenous communities where rates of gonococcal disease are 627.5 per 100,000 population or higher, a disease burden among the highest in the developed world [52].

\section{Conclusions}

Interest in the development of a vaccine against $N$. gonorrhoeae has grown in recent years, given the increasing reports of AMR strains and the promising evidence of crossprotection of MenB vaccines indicating the biological feasibility of a gonococcal vaccine. A successful gonococcal vaccine will need to induce a protective immune response greater than that generated during natural infection and counteract or overcome the mechanisms used by the bacteria to evade the adaptive immune response. In addition, there are many implementation issues with a gonorrhea vaccine. While there has been some success for vaccines against STIs, including the hepatitis B virus and human papillomavirus, these vaccines are not promoted as STI vaccines but rather as vaccines for hepatitis/hepatic cancer and cervical cancer, respectively $[163,164]$.

While it is promising that a population-based vaccination strategy ( 3 months to 24 years) of a low efficacy vaccine such as the VA-MENGOC-BC vaccine in Cuba has resulted in a reduction of gonorrhea, the tantalizing prospect of a high-efficacy vaccine delivered directly to adult at-risk groups may circumvent public perceptions but increase the cost of vaccine production.

Clearly articulating the benefits of a gonorrhea vaccine by reducing the economic burden on society in general, controlling the spread of AMR N. gonorrhoeae and their threat to over-the-counter treatment and improving women's health specifically are all necessary for preparing a successful implementation strategy (see [13] for a full report).

Author Contributions: All authors contributed to the writing of the manuscript. E.C.H. and C.M.K. edited the manuscript. C.M.K. reviewed and approved the manuscript. All authors have read and agreed to the published version of the manuscript.

Funding: E.C.H. is supported by the Research Training Program (RTP) PhD scholarship from the University of Western Australia and V.C.T. is supported by the University International Fee Scholarship (UIFS) and University Postgraduate Award (International Students) (UPAIS) from the University of Western Australia.

Institutional Review Board Statement: Not applicable.

Informed Consent Statement: Not applicable.

Data Availability Statement: Not applicable.

Conflicts of Interest: The authors declare no conflict of interest. 


\section{References}

1. Rowley, J.; Hoorn, S.V.; Korenromp, E.; Low, N.; Unemo, M.; Abu-Raddad, L.J.; Chico, R.M.; Smolak, A.; Newman, L.; Gottlieb, S.; et al. Chlamydia, Gonorrhoea, Trichomoniasis and Syphilis: Global Prevalence and Incidence Estimates, 2016. Bull. World Health Organ. 2019, 97, 548-562. [CrossRef]

2. Korenromp, E.L.; Wi, T.; Resch, S.; Stover, J.; Broutet, N. Costing of National STI Program Implementation for the Global STI Control Strategy for the Health Sector, 2016-2021. PLoS ONE 2017, 12, e0170773. [CrossRef]

3. Inhorn, M.C.; Patrizio, P. Infertility around the Globe: New Thinking on Gender, Reproductive Technologies and Global Movements in the 21st Century. Hum. Reprod. Update 2015, 21, 411-426. [CrossRef]

4. Chesson, H.W.; Spicknall, I.H.; Bingham, A.; Brisson, M.; Eppink, S.T.; Farnham, P.G.; Kreisel, K.M.; Kumar, S.; Laprise, J.-F.; Peterman, T.A.; et al. The Estimated Direct Lifetime Medical Costs of Sexually Transmitted Infections Acquired in the United States in 2018. Sex. Transm. Dis. 2021, 48, 215-221. [CrossRef] [PubMed]

5. Owusu-Edusei, K., Jr.; Chesson, H.W.; Gift, T.L.; Tao, G.; Mahajan, R.; Ocfemia, M.C.B.; Kent, C.K. The Estimated Direct Medical Cost of Selected Sexually Transmitted Infections in the United States, 2008. Sex. Transm. Dis. 2013, 40, 197-201. [CrossRef] [PubMed]

6. Chesson, H.W.; Kirkcaldy, R.D.; Gift, T.L.; Owusu-Edusei, K.; Weinstock, H.S. An Illustration of the Potential Health and Economic Benefits of Combating Antibiotic-Resistant Gonorrhea. Sex. Transm. Dis. 2018, 45, 250-253. [CrossRef] [PubMed]

7. Unemo, M.; Lahra, M.M.; Cole, M.; Galarza, P.; Ndowa, F.; Martin, I.; Dillon, J.-A.R.; Ramon-Pardo, P.; Bolan, G.; Wi, T. World Health Organization Global Gonococcal Antimicrobial Surveillance Program (WHO GASP): Review of New Data and Evidence to Inform International Collaborative Actions and Research Efforts. Sex. Health 2019, 16, 412-425. [CrossRef]

8. World Health Organization. Global Priority List of Antibiotic-Resistant Bacteria to Guide Research, Discovery, and Development of New Antibiotics; World Health Organization: Geneva, Switzerland, 2017; pp. 1-7.

9. Broutet, N.; Fruth, U.; Deal, C.; Gottlieb, S.L.; Rees, H.; Participants of the 2013 STI Vaccine Technical Consultation. Vaccines against Sexually Transmitted Infections: The Way Forward. Vaccine 2014, 32, 1630-1637. [CrossRef] [PubMed]

10. Gottlieb, S.L.; Jerse, A.E.; Delany-Moretlwe, S.; Deal, C.; Giersing, B.K. Advancing Vaccine Development for Gonorrhoea and the Global STI Vaccine Roadmap. Sex. Health 2019, 16, 426-432. [CrossRef] [PubMed]

11. Gottlieb, S.L.; Deal, C.D.; Giersing, B.; Rees, H.; Bolan, G.; Johnston, C.; Timms, P.; Gray-Owen, S.D.; Jerse, A.E.; Cameron, C.E.; et al. The Global Roadmap for Advancing Development of Vaccines against Sexually Transmitted Infections: Update and Next Steps. Vaccine 2016, 34, 2939-2947. [CrossRef]

12. Wetzler, L.M.; Feavers, I.M.; Gray-Owen, S.D.; Jerse, A.E.; Rice, P.A.; Deal, C.D. Summary and Recommendations from the National Institute of Allergy and Infectious Diseases (NIAID) Workshop "Gonorrhea Vaccines: The Way Forward". Clin. Vaccine Immunol. 2016, 23, 656-663. [CrossRef]

13. Gottlieb, S.L.; Ndowa, F.; Hook, E.W., III; Deal, C.; Bachmann, L.; Abu-Raddad, L.; Chen, X.-S.; Jerse, A.E.; Low, N.; MacLennan, C.A.; et al. Gonococcal Vaccines: Public Health Value and Preferred Product Characteristics; Report of A WHO Global Stakeholder Consultation, January 2019. Vaccine 2020, 38, 4362-4373. [CrossRef]

14. Wellcome Trust and BCG. Vaccines to Tackle Drug Resistant Infections. An Evaluation of RED Opportunities. Executive Summary; Wellcome Trust: London, UK, 2018.

15. Petousis-Harris, H.; Paynter, J.; Morgan, J.; Saxton, P.; McArdle, B.; Goodyear-Smith, F.; Black, S. Effectiveness of A Group B Outer Membrane Vesicle Meningococcal Vaccine against Gonorrhoea in New Zealand: A Retrospective Case-Control Study. Lancet 2017, 390, 1603-1610. [CrossRef]

16. Ochoa-Azze, R.F. A Meningococcal B Vaccine Induces Cross-Protection against Gonorrhea. Clin. Exp. Vaccine Res. 2019, 8, 110-115. [CrossRef]

17. Leduc, I.; Connolly, K.L.; Begum, A.; Underwood, K.; Darnell, S.; Shafer, W.M.; Balthazar, J.T.; Macintyre, A.N.; Sempowski, G.D.; Duncan, J.A.; et al. The Serogroup B Meningococcal Outer Membrane Vesicle-Based Vaccine 4CMenB Induces Cross-Species Protection against Neisseria gonorrhoeae. PLoS Pathog. 2020, 16, e1008602. [CrossRef] [PubMed]

18. Kirkcaldy, R.D.; Weston, E.; Segurado, A.C.; Hughes, G. Epidemiology of Gonorrhoea: A Global Perspective. Sex. Health 2019, 16, 401-411. [CrossRef] [PubMed]

19. Hui, B.; Fairley, C.K.; Chen, M.; Grulich, A.; Hocking, J.; Prestage, G.; Walker, S.; Law, M.; Regan, D. Oral and Anal Sex Are Key to Sustaining Gonorrhoea at Endemic Levels in MSM Populations: A Mathematical Model. Sex. Transm. Infect. 2015, 91, 365-369. [CrossRef]

20. Schofield, C.B. Some Factors Affecting the Incubation Period and Duration of Symptoms of Urethritis in Men. Br. J. Vener. Dis. 1982, 58, 184-187. [CrossRef] [PubMed]

21. Sherrard, J.; Barlow, D. Gonorrhoea in Men: Clinical and Diagnostic Aspects. Genitourin. Med. 1996, 72, 422-426. [CrossRef]

22. Ong, J.J.; Fethers, K.; Howden, B.P.; Fairley, C.K.; Chow, E.P.F.; Williamson, D.A.; Petalotis, I.; Aung, E.; Kanhutu, K.; De Petra, V.; et al. Asymptomatic and Symptomatic Urethral Gonorrhoea in Men Who Have Sex with Men Attending A Sexual Health Service. Clin. Microbiol. Infect. 2017, 23, 555-559. [CrossRef] [PubMed]

23. Lovett, A.; Duncan, J.A. Human Immune Responses and the Natural History of Neisseria gonorrhoeae Infection. Front. Immunol. 2019, 9, 1-10. [CrossRef] [PubMed] 
24. Martín-Sánchez, M.; Ong, J.J.; Fairley, C.K.; Chen, M.Y.; Williamson, D.A.; Maddaford, K.; Aung, E.T.; Carter, G.; Bradshaw, C.S.; Chow, E.P.F. Clinical Presentation of Asymptomatic and Symptomatic Heterosexual Men Who Tested Positive for Urethral Gonorrhoea at A Sexual Health Clinic in Melbourne, Australia. BMC Infect. Dis. 2020, 20, 486. [CrossRef] [PubMed]

25. Platt, R.; Rice, P.A.; McCormack, W.M. Risk of Acquiring Gonorrhea and Prevalence of Abnormal Adnexal Findings among Women Recently Exposed to Gonorrhea. JAMA 1983, 250, 3205-3209. [CrossRef]

26. Barlow, D.; Phillips, I. Gonorrhoea in Women: Diagnostic, Clinical, and Laboratory Aspects. Lancet 1978, 311, 761-764. [CrossRef]

27. Chan, P.A.; Robinette, A.; Montgomery, M.; Almonte, A.; Cu-Uvin, S.; Lonks, J.R.; Chapin, K.C.; Kojic, E.M.; Hardy, E.J. Extragenital Infections Caused by Chlamydia trachomatis and Neisseria gonorrhoeae: A Review of the Literature. Infect. Dis. Obstet. Gynecol. 2016, 2016, 17. [CrossRef] [PubMed]

28. Edwards, J.L.; Apicella, M.A. The Molecular Mechanisms Used by Neisseria gonorrhoeae to Initiate Infection Differ between Men and Women. Clin. Microbiol. Rev. 2004, 17, 965-981. [CrossRef]

29. Cannon, J.G.; Buchanan, T.M.; Sparling, P.F. Confirmation of Association of Protein I Serotype of Neisseria gonorrhoeae with Ability to Cause Disseminated Infection. Infect. Immun. 1983, 40, 816-819. [CrossRef] [PubMed]

30. Vidaurrazaga, M.M.; Perlman, D.C. A Case of Purulent Gonococcal Arthritis. IDCases 2020, 19, e00662. [CrossRef] [PubMed]

31. Oh, S.; Kim, S.-H.; Baek, J.Y.; Huh, K.; Cho, S.Y.; Kang, C.-I.; Chung, D.R.; Huh, H.J.; Lee, N.Y.; Peck, K.R. A Case of Gonococcal Meningitis Caused by Neisseria gonorrhoeae MLST ST7363 in A Healthy Young Adult. J. Infect. Chemother. 2020, 26, 995-998. [CrossRef]

32. Neto, A.; Sevilha, J.; Seabra, D.; Oliveira, I.; Santos, R.P.; Andrade, A.; Pinho, P.; Costa, P.M.; Viana, M.; Pinto, P. Acute aortic Regurgitation due to Endocarditis Caused by Disseminated Gonococcal Infection: A Case Report. Sex. Transm. Dis. 2021, 48, e48-e50. [CrossRef]

33. Ramos, A.; García-Pavía, P.; Orden, B.; Cobo, M.; Sánchez-Castilla, M.; Sánchez-Romero, I.; Múñez, E.; Marín, M.; García-Montero, C. Gonococcal Endocarditis: A Case Report and Review of the Literature. Infection 2014, 42, 425-428. [CrossRef] [PubMed]

34. Mathew, R.; Chahin, M.; Isache, C. Neisseria gonorrhoeae: An Unexpected Cause of Polyarthritis and Meningitis. J. Investig. Med. High Impact Case Rep. 2021, 9, 1-4. [CrossRef]

35. Malott, R.J.; Keller, B.O.; Gaudet, R.G.; McCaw, S.E.; Lai, C.C.L.; Dobson-Belaire, W.N.; Hobbs, J.L.; Michael, F.; Cox, A.D.; Moraes, T.F.; et al. Neisseria gonorrhoeae-Derived Heptose Elicits An Innate Immune Response and Drives HIV-1 Expression. Proc. Natl. Acad. Sci. USA 2013, 110, 10234-10239. [CrossRef] [PubMed]

36. Fleming, D.T.; Wasserheit, J.N. From Epidemiological Synergy to Public Health Policy and Practice: The Contribution of Other Sexually Transmitted Diseases to Sexual Transmission of HIV Infection. Sex. Transm. Infect. 1999, 75, 3-17. [CrossRef]

37. Cohen, M.S.; Hoffman, I.F.; Royce, R.A.; Kazembe, P.; Dyer, J.R.; Daly, C.C.; Zimba, D.; Vernazza, P.L.; Maida, M.; Fiscus, S.A.; et al. Reduction of Concentration of HIV-1 in Semen after Treatment of Urethritis: Implications for Prevention of Sexual Transmission of HIV-1. Lancet 1997, 349, 1868-1873. [CrossRef]

38. Cohen, M.S. Sexually Transmitted Diseases Enhance HIV Transmission: No Longer a Hypothesis. Lancet 1998, 351, S5-S7. [CrossRef]

39. Galvin, S.R.; Cohen, M.S. The Role of Sexually Transmitted Diseases in HIV Transmission. Nat. Rev. Microbiol. $2004,2,33-42$. [CrossRef]

40. Viglianti, G.A.; Planelles, V.; Hanley, T.M. Interactions with Commensal and Pathogenic Bacteria Induce HIV-1 Latency in Macrophages through Altered Transcription Factor Recruitment to the Long Terminal Repeat. J. Virol. 2021, 95, e02141-20. [CrossRef]

41. Brunham, R.C.; Gottlieb, S.L.; Paavonen, J. Pelvic Inflammatory Disease. N. Engl. J. Med. 2015, 372, 2039-2048. [CrossRef] [PubMed]

42. Weström, L.; Joesoef, R.; Reynolds, G.; Hagdu, A.; Thompson, S.E. Pelvic Inflammatory Disease and Fertility: A Cohort Study of 1844 Women with Laparoscopically Verified Disease and 657 Control Women with Normal Laparoscopic Results. Sex. Transm. Dis. 1992, 19, 185-192. [CrossRef]

43. Gray-Swain, M.R.; Peipert, J.F. Pelvic Inflammatory Disease in Adolescents. Curr. Opin. Obstet. Gynecol. 2006, 18, 503-510. [CrossRef] [PubMed]

44. Wiesenfeld, H.C.; Hillier, S.L.; Meyn, L.A.; Amortegui, A.J.; Sweet, R.L. Subclinical Pelvic Inflammatory Disease and Infertility. Obstet. Gynecol. 2012, 120, 37-43. [CrossRef]

45. Vallely, L.M.; Egli-Gany, D.; Wand, H.; Pomat, W.S.; Homer, C.S.E.; Guy, R.; Silver, B.; Rumbold, A.R.; Kaldor, J.M.; Vallely, A.J.; et al. Adverse Pregnancy and Neonatal Outcomes Associated with Neisseria gonorrhoeae: Systematic Review and Metaanalysis. Sex. Transm. Infect. 2021, 97, 104-111. [CrossRef] [PubMed]

46. Reekie, J.; Donovan, B.; Guy, R.; Hocking, J.S.; Kaldor, J.M.; Mak, D.B.; Pearson, S.; Preen, D.; Stewart, L.; Ward, J.; et al. Risk of Pelvic Inflammatory Disease in Relation to Chlamydia and Gonorrhea Testing, Repeat Testing, and Positivity: A Population-Based Cohort Study. Clin. Infect. Dis. 2018, 66, 437-443. [CrossRef] [PubMed]

47. Taylor, B.D.; Ness, R.B.; Darville, T.; Haggerty, C.L. Microbial Correlates of Delayed Care for Pelvic Inflammatory Disease. Sex. Transm. Dis. 2011, 38, 434-438. [CrossRef]

48. Kirby Institute. National Update on HIV, Viral Hepatitis and Sexually Transmissible Infections in Australia: 2009-2018; Kirby Institute, UNSW Sydney: Sydney, Australia, 2020. 
49. Lahra, M.M.; Shoushtari, M.; George, C.R.R.; Armstrong, B.H.; Hogan, T.R. Australian Gonococcal Surveillance Programme Annual Report, 2019. Commun. Dis. Intell. 2020, 44, 1-15. [CrossRef]

50. Kirby Institute. HIV, Viral Hepatitis and Sexually Transmissible Infections in Australia: Annual Surveillance Report 2018; Kirby Institute, UNSW Sydney: Sydney, Australia, 2018.

51. Kirby Institute. HIV, Viral Hepatitis and Sexually Transmissible Infections in Australia: Annual Surveillance Report 2017; Kirby Institute, UNSW Sydney: Sydney, Australia, 2017.

52. Kirby Institute. Bloodborne Viral and Sexually Transmissible Infections in Aboriginal and Torres Strait Islander People: Annual Surveillance Report 2018; Kirby Institute, UNSW Sydney: Sydney, Australia, 2018.

53. Callander, D.; Wiggins, J.; Rosenberg, S.; Cornelisse, V.J.; Duck-Chong, E.; Holt, M.; Pony, M.; Vlahakis, E.; MacGibbon, J.; Cook, T. The 2018 Australian Trans and Gender Diverse Sexual Health Survey: Report of Findings; Kirby Institute, UNSW Sydney: Sydney, Australia, 2019.

54. Callander, D.; McManus, H.; Guy, R.; Hellard, M.; O'Connor, C.C.; Fairley, C.K.; Chow, E.P.F.; McNulty, A.; Lewis, D.A.; Carmody, C.; et al. Rising Chlamydia and Gonorrhoea Incidence and Associated Risk Factors among Female Sex Workers in Australia: A Retrospective Cohort Study. Sex. Transm. Dis. 2018, 45, 199-206. [CrossRef]

55. Chow, E.P.; Williamson, D.A.; Fortune, R.; Bradshaw, C.S.; Chen, M.Y.; Fehler, G.; De Petra, V.; Howden, B.P.; Fairley, C.K. Prevalence of Genital and Oropharyngeal Chlamydia and Gonorrhoea among Female Sex Workers in Melbourne, Australia, 2015-2017: Need for Oropharyngeal Testing. Sex. Transm. Infect. 2019, 95, 398-401. [CrossRef]

56. Callander, D.; Read, P.; Prestage, G.; Minichiello, V.; Chow, E.P.F.; Lewis, D.A.; McNulty, A.; Ali, H.; Hellard, M.; Guy, R.; et al. A Cross-Sectional Study of HIV and STIs among Male Sex Workers Attending Australian Sexual Health Clinics. Sex. Transm. Infect. 2017, 93, 299-302. [CrossRef] [PubMed]

57. Turek, E.M.; Fairley, C.K.; Tabesh, M.; Phillips, T.R.; Bradshaw, C.S.; Rodriguez, E.; Chow, E.P.F. HIV, Sexually Transmitted Infections and Sexual Practices among Male Sex Workers Attending A Sexual Health Clinic in Melbourne, Australia: 2010 to 2018. Sex. Transm. Dis. 2021, 48, 103-108. [CrossRef]

58. Callander, D.; Guy, R.; Fairley, C.K.; McManus, H.; Prestage, G.; Chow, E.P.F.; Chen, M.; Connor, C.C.O.; Grulich, A.E.; Bourne, C.; et al. Gonorrhoea Gone Wild: Rising Incidence of Gonorrhoea and Associated Risk Factors among Gay and Bisexual Men Attending Australian Sexual Health Clinics. Sex. Health 2019, 16, 457-463. [CrossRef]

59. Martín-Sánchez, M.; Case, R.; Fairley, C.; Hocking, J.S.; Bradshaw, C.; Ong, J.; Chen, M.Y.; Chow, E.P.F. Trends and Differences in Sexual Practices and Sexually Transmitted Infections in Men Who Have Sex with Men Only (MSMO) and Men Who Have Sex with Men and Women (MSMW): A Repeated Cross-Sectional Study in Melbourne, Australia. BMJ Open 2020, 10 , e037608. [CrossRef] [PubMed]

60. Richards, C.; Bouman, W.P.; Seal, L.; Barker, M.J.; Nieder, T.O.; T'Sjoen, G. Non-Binary or Genderqueer Genders. Int. Rev. Psychiatry 2016, 28, 95-102. [CrossRef] [PubMed]

61. Callander, D.; Cook, T.; Read, P.; Hellard, M.E.; Fairley, C.K.; Kaldor, J.M.; Vlahakis, E.; Pollack, A.; Bourne, C.; Russell, D.B.; et al. Sexually Transmissible Infections among Transgender Men and Women Attending Australian Sexual Health Clinics. Med. J. Aust. 2019, 211, 406-411. [CrossRef] [PubMed]

62. Bellhouse, C.; Walker, S.; Fairley, C.K.; Vodstrcil, L.A.; Bradshaw, C.S.; Chen, M.Y.; Chow, E.P.F. Patterns of Sexual Behaviour and Sexual Healthcare Needs among Transgender Individuals in Melbourne, Australia, 2011-2014. Sex. Transm. Infect. 2018, 94, 212-215. [CrossRef]

63. Graham, S.; Guy, R.J.; Donovan, B.; McManus, H.; Su, J.Y.; El-Hayek, C.; Kwan, K.S.H.; Dyda, A.; Wand, H.C.; Ward, J.S. Epidemiology of Chlamydia and Gonorrhoea among Indigenous and Non-Indigenous Australians, 2000-2009. Med. J. Aust. 2012, 197, 642-646. [CrossRef] [PubMed]

64. Wi, T.; Lahra, M.M.; Ndowa, F.; Bala, M.; Dillon, J.-A.R.; Ramon-Pardo, P.; Eremin, S.R.; Bolan, G.; Unemo, M. Antimicrobial Resistance in Neisseria gonorrhoeae: Global Surveillance and A Call for International Collaborative Action. PLoS Med. 2017, 14, 1-16. [CrossRef] [PubMed]

65. World Health Organization. WHO Guidelines for the Treatment of Neisseria gonorrhoeae; World Health Organization: Geneva, Switzerland, 2016; pp. 1-55.

66. Ohnishi, M.; Saika, T.; Hoshina, S.; Iwasaku, K.; Nakayama, S.-I.; Watanabe, H.; Kitawaki, J. Ceftriaxone-Resistant Neisseria gonorrhoeae, Japan. Emerg. Infect. Dis. 2011, 17, 148-149. [CrossRef]

67. Golparian, D.; Ohlsson, A.K.; Janson, H.; Lidbrink, P.; Richtner, T.; Ekelund, O.; Fredlund, H.; Unemo, M. Four Treatment Failures of Pharyngeal Gonorrhoea with Ceftriaxone (500 mg) or Cefotaxime (500 mg), Sweden, 2013 and 2014. Eurosurveillance 2014, 19, 20862. [CrossRef]

68. Unemo, M.; Golparian, D.; Hestner, A. Ceftriaxone Treatment Failure of Pharyngeal Gonorrhoea Verified by International Recommendations, Sweden, July 2010. Eurosurveillance 2011, 16, 19792. [CrossRef] [PubMed]

69. Chen, M.Y.; Stevens, K.; Tideman, R.; Zaia, A.; Tomita, T.; Fairley, C.K.; Lahra, M.; Whiley, D.; Hogg, G. Failure of 500 mg of Ceftriaxone to Eradicate Pharyngeal Gonorrhoea, Australia. J. Antimicrob. Chemother. 2013, 68, 1445-1447. [CrossRef]

70. Tapsall, J.; Read, P.; Carmody, C.; Bourne, C.; Ray, S.; Limnios, A.; Sloots, T.; Whiley, D. Two Cases of Failed Ceftriaxone Treatment in Pharyngeal Gonorrhoea Verified by Molecular Microbiological Methods. J. Med. Microbiol. 2009, 58, 683-687. [CrossRef]

71. Read, P.J.; Limnios, E.A.; McNulty, A.; Whiley, D.; Lahra, M.M. One Confirmed and One Suspected Case of Pharyngeal Gonorrhoea Treatment Failure Following 500mg Ceftriaxone in Sydney, Australia. Sex. Health 2013, 10, 460-462. [CrossRef] 
72. Unemo, M.; Golparian, D.; Potočnik, M.; Jeverica, S. Treatment Failure of Pharyngeal Gonorrhoea with Internationally Recommended First-Line Ceftriaxone Verified in Slovenia, September 2011. Eurosurveillance 2012, 17. [CrossRef]

73. Fifer, H.; Natarajan, U.; Jones, L.; Alexander, S.; Hughes, G.; Golparian, D.; Unemo, M. Failure of Dual Antimicrobial Therapy in Treatment of Gonorrhea. N. Engl. J. Med. 2016, 374, 2504-2506. [CrossRef]

74. Nakayama, S.-I.; Shimuta, K.; Furubayashi, K.-I.; Kawahata, T.; Unemo, M.; Ohnishi, M. New Ceftriaxone- and Multidrugresistant Neisseria gonorrhoeae Strain with A Novel Mosaic penA Gene Isolated in Japan. Antimicrob. Agents Chemother. 2016, 60, 4339-4341. [CrossRef]

75. Terkelsen, D.; Tolstrup, J.; Johnsen, C.H.; Lund, O.; Larsen, H.K.; Worning, P.; Unemo, M.; Westh, H. Multidrug-Resistant Neisseria gonorrhoeae Infection with Ceftriaxone Resistance and Intermediate Resistance to Azithromycin, Denmark, 2017. Eurosurveillance 2017, 22, 17-00659. [CrossRef]

76. Eyre, D.W.; Town, K.; Street, T.; Barker, L.; Sanderson, N.; Cole, M.J.; Mohammed, H.; Pitt, R.; Gobin, M.; Irish, C.; et al. Detection in the United Kingdom of the Neisseria gonorrhoeae FC428 Clone, with Ceftriaxone Resistance and Intermediate Resistance to Azithromycin, October to December 2018. Eurosurveillance 2019, 24, 1900147. [CrossRef]

77. Golparian, D.; Rose, L.; Lynam, A.; Mohamed, A.; Bercot, B.; Ohnishi, M.; Crowley, B.; Unemo, M. Multidrug-Resistant Neisseria gonorrhoeae Isolate, Belonging to the Internationally Spreading Japanese FC428 Clone, with Ceftriaxone Resistance and Intermediate Resistance to Azithromycin, Ireland, August 2018. Eurosurveillance 2018, 23, 1800617. [CrossRef]

78. Poncin, T.; Fouere, S.; Braille, A.; Camelena, F.; Agsous, M.; Bebear, C.; Kumanski, S.; Lot, F.; Mercier-Delarue, S.; Ngangro, N.N.; et al. Multidrug-Resistant Neisseria gonorrhoeae Failing Treatment with Ceftriaxone and Doxycycline in France, November 2017. Eurosurveillance 2018, 23, 1800264. [CrossRef]

79. Lahra, M.M.; Martin, I.; Demczuk, W.; Jennison, A.V.; Lee, K.-I.; Nakayama, S.-I.; Lefebvre, B.; Longtin, J.; Ward, A.; Mulvey, M.R.; et al. Cooperative Recognition of Internationally Disseminated Ceftriaxone-Resistant Neisseria gonorrhoeae Strain. Emerg. Infect. Dis. 2018, 24, 735-740. [CrossRef]

80. Lefebvre, B.; Martin, I.; Demczuk, W.; Deshaies, L.; Michaud, S.; Labbé, A.-C.; Beaudoin, M.-C.; Longtin, J. Ceftriaxone-Resistant Neisseria gonorrhoeae, Canada, 2017. Emerg. Infect. Dis. 2018, 24, 381-383. [CrossRef]

81. Eyre, D.W.; Sanderson, N.D.; Lord, E.; Regisford-Reimmer, N.; Chau, K.; Barker, L.; Morgan, M.; Newnham, R.; Golparian, D.; Unemo, M.; et al. Gonorrhoea Treatment Failure Caused by A Neisseria gonorrhoeae Strain with Combined Ceftriaxone and High-Level Azithromycin Resistance, England, February 2018. Eurosurveillance 2018, 23, 1-6. [CrossRef]

82. Jennison, A.V.; Whiley, D.; Lahra, M.M.; Graham, R.M.; Cole, M.J.; Hughes, G.; Fifer, H.; Andersson, M.; Edwards, A.; Eyre, D. Genetic Relatedness of Ceftriaxone-Resistant and High-Level Azithromycin Resistant Neisseria gonorrhoeae Cases, United Kingdom and Australia, February to April 2018. Eurosurveillance 2019, 24, 1900118. [CrossRef]

83. Whiley, D.M.; Jennison, A.; Pearson, J.; Lahra, M.M. Genetic Characterisation of Neisseria gonorrhoeae Resistant to both Ceftriaxone and Azithromycin. Lancet Infect. Dis. 2018, 18, 717-718. [CrossRef]

84. Jefferson, A.; Smith, A.; Fasinu, P.S.; Thompson, D.K. Sexually Transmitted Neisseria gonorrhoeae Infections-Update on Drug Treatment and Vaccine Development. Medicines 2021, 8, 11. [CrossRef]

85. Yan, F.; Gao, F. A Systematic Strategy for the Investigation of Vaccines and Drugs Targeting Bacteria. Comput. Struct. Biotechnol. J. 2020, 18, 1525-1538. [CrossRef]

86. Lim, K.Y.L.; Mullally, C.A.; Haese, E.C.; Kibble, E.A.; McCluskey, N.R.; Mikucki, E.C.; Thai, V.C.; Stubbs, K.A.; Sarkar-Tyson, M.; Kahler, C.M. Anti-Virulence Therapeutic Approaches for Neisseria gonorrhoeae. Antibiotics 2021, 10, 103. [CrossRef]

87. Kahler, C.M. Multidrug-Resistant Neisseria gonorrhoeae: Future Therapeutic Options. Future Microbiol. 2018, 13, 499-501. [CrossRef]

88. Abara, W.E.; Jerse, A.E.; Hariri, S.; Kirkcaldy, R.D. Planning for A Gonococcal Vaccine: A Narrative Review of Vaccine Development and Public Health Implications. Sex. Transm. Dis. 2020, 48, 453-457. [CrossRef]

89. Hedges, S.R.; Sibley, D.A.; Mayo, M.S.; Hook, E.W., III; Russell, M.W. Cytokine and Antibody Responses in Women Infected with Neisseria gonorrhoeae: Effects of Concomitant Infections. J. Infect. Dis. 1998, 178, 742-751. [CrossRef] [PubMed]

90. Hedges, S.R.; Mayo, M.S.; Mestecky, J.; Hook, E.W., III; Russell, M.W. Limited Local and Systemic Antibody Responses to Neisseria gonorrhoeae during Uncomplicated Genital Infections. Infect. Immun. 1999, 67, 3937-3946. [CrossRef]

91. Fung, M.; Scott, K.C.; Kent, C.K.; Klausner, J.D. Chlamydial and Gonococcal Reinfection among Men: A Systematic Review of Data to Evaluate the Need for Retesting. Sex. Transm. Infect. 2007, 83, 304-309. [CrossRef] [PubMed]

92. Jerse, A.E.; Wu, H.; Packiam, M.; Vonck, R.A.; Begum, A.A.; Garvin, L.E. Estradiol-Treated Female Mice as Surrogate Hosts for Neisseria gonorrhoeae Genital Tract Infections. Front. Microbiol. 2011, 2, 107. [CrossRef] [PubMed]

93. Rice, P.A.; Shafer, W.M.; Ram, S.; Jerse, A.E. Neisseria gonorrhoeae: Drug Resistance, Mouse Models, and Vaccine Development. Annu. Rev. Microbiol. 2017, 71, 665-686. [CrossRef]

94. Stern, A.; Brown, M.; Nickel, P.; Meyer, T.F. Opacity Genes in Neisseria gonorrhoeae: Control of Phase and Antigenic Variation. Cell 1986, 47, 61-71. [CrossRef]

95. Seifert, H.S.; Wright, C.J.; Jerse, A.E.; Cohen, M.S.; Cannon, J.G. Multiple Gonococcal Pilin Antigenic Variants Are Produced during Experimental Human Infections. J. Clin. Investig. 1994, 93, 2744-2749. [CrossRef]

96. Cahoon, L.A.; Seifert, H.S. Focusing Homologous Recombination: Pilin Antigenic Variation in the Pathogenic Neisseria. Mol. Microbiol. 2011, 81, 1136-1143. [CrossRef]

97. Harvey, H.A.; Swords, W.E.; Apicella, M.A. The Mimicry of Human Glycolipids and Glycosphingolipids by the Lipooligosaccharides of Pathogenic Neisseria and Haemophilus. J. Autoimmun. 2001, 16, 257-262. [CrossRef] [PubMed] 
98. Binker, M.G.; Cosen-Binker, L.I.; Terebiznik, M.R.; Mallo, G.V.; McCaw, S.E.; Eskelinen, E.-L.; Willenborg, M.; Brumell, J.H.; Saftig, P.; Grinstein, S.; et al. Arrested Maturation of Neisseria-Containing Phagosomes in the Absence of the Lysosome-Associated Membrane Proteins, LAMP-1 and LAMP-2. Cell. Microbiol. 2007, 9, 2153-2166. [CrossRef]

99. Huynh, K.K.; Eskelinen, E.-L.; Scott, C.C.; Malevanets, A.; Saftig, P.; Grinstein, S. LAMP Proteins Are Required for Fusion of Lysosomes with Phagosomes. EMBO J. 2007, 26, 313-324. [CrossRef]

100. Chen, T.; Grunert, F.; Medina-Marino, A.; Gotschlich, E.C. Several Carcinoembryonic Antigens (CD66) Serve as receptors for Gonococcal Opacity Proteins. J. Exp. Med. 1997, 185, 1557-1564. [CrossRef]

101. Boulton, I.C.; Gray-Owen, S.D. Neisserial Binding to CEACAM1 Arrests the Activation and Proliferation of CD4+ T Lymphocytes. Nat. Immunol. 2002, 3, 229-236. [CrossRef]

102. Zariri, A.; Van Dijken, H.; Hamstra, H.-J.; Van Der Flier, M.; Vidarsson, G.; Van Putten, J.P.M.; Boog, C.J.P.; Van Den Dobbelsteen, G.; Van Der Ley, P. Expression of Human CEACAM1 in Transgenic Mice Limits the Opa-Specific Immune Response against Meningococcal Outer Membrane Vesicles. Vaccine 2013, 31, 5585-5593. [CrossRef]

103. Zhu, W.; Ventevogel, M.S.; Knilans, K.J.; Anderson, J.E.; Oldach, L.M.; McKinnon, K.P.; Hobbs, M.M.; Sempowski, G.D.; Duncan, J.A. Neisseria gonorrhoeae Suppresses Dendritic Cell-Induced, Antigen-Dependent CD4 T Cell Proliferation. PLoS ONE 2012, 7, e41260. [CrossRef]

104. Zhu, W.; Tomberg, J.; Knilans, K.J.; Anderson, J.E.; McKinnon, K.P.; Sempowski, G.D.; Nicholas, R.A.; Duncan, J.A. Properly Folded and Functional PorB from Neisseria gonorrhoeae Inhibits Dendritic Cell Stimulation of CD4 + T Cell Proliferation. J. Biol. Chem. 2018, 293, 11218-11229. [CrossRef] [PubMed]

105. Criss, A.K.; Seifert, H.S. A Bacterial Siren Song: Intimate Interactions between Neisseria and Neutrophils. Nat. Rev. Microbiol. 2012, 10, 178-190. [CrossRef]

106. Palmer, A.; Criss, A.K. Gonococcal Defenses against Antimicrobial Activities of Neutrophils. Trends Microbiol. 2018, 26, 1022-1034. [CrossRef] [PubMed]

107. Escobar, A.; Rodas, P.I.; Acuña-Castillo, C. Macrophage-Neisseria gonorrhoeae Interactions: A Better Understanding of Pathogen Mechanisms of Immunomodulation. Front. Immunol. 2018, 9, 1-8. [CrossRef] [PubMed]

108. Château, A.; Seifert, H.S. Neisseria gonorrhoeae Survives within and Modulates Apoptosis and Inflammatory Cytokine Production of Human Macrophages. Cell. Microbiol. 2016, 18, 546-560. [CrossRef]

109. Escobar, A.; Candia, E.; Reyes-Cerpa, S.; Villegas-Valdes, B.; Neira, T.; Lopez, M.; Maisey, K.; Tempio, F.; Ríos, M.; Acuña-Castillo, C.; et al. Neisseria gonorrhoeae Induces A Tolerogenic Phenotype in Macrophages to Modulate Host Immunity. Mediat. Inflamm. 2013, 2013, 127017. [CrossRef]

110. Ortiz, M.C.; Lefimil, C.; Rodas, P.I.; Vernal, R.; Lopez, M.; Acuña-Castillo, C.; Imarai, M.; Escobar, A. Neisseria gonorrhoeae Modulates Immunity by Polarizing Human Macrophages to A M2 Profile. PLoS ONE 2015, 10, e0130713. [CrossRef]

111. Viola, A.; Munari, F.; Sánchez-Rodríguez, R.; Scolaro, T.; Castegna, A. The Metabolic Signature of Macrophage Responses. Front. Immunol. 2019, 10, 1426. [CrossRef]

112. Sica, A.; Mantovani, A. Macrophage Plastic ity and Polariation: In Vivo Veritas. J. Clin. Investig. 2012, 122, 787-795. [CrossRef] [PubMed]

113. Biswas, S.K.; Mantovani, A. Macrophage Plasticity and Interaction with lymphocyte Subsets: Cancer as A Paradigm. Nat. Immunol. 2010, 11, 889-896. [CrossRef] [PubMed]

114. Feinen, B.; Jerse, A.E.; Gaffen, S.L.; Russell, M.W. Critical Role of Th17 Responses in A Murine Model of Neisseria gonorrhoeae Genital Infection. Mucosal Immunol. 2010, 3, 312-321. [CrossRef]

115. Liu, Y.; Islam, E.A.; Jarvis, G.A.; Gray-Owen, S.D.; Russell, M.W. Neisseria gonorrhoeae Selectively Suppresses the Development of Th1 and Th2 Cells, and Enhances Th17 Cell Responses, through TGF- $\beta$-Dependent Mechanisms. Mucosal Immunol. 2012, 5 , 320-331. [CrossRef]

116. Gulati, S.; Mu, X.; Zheng, B.; Reed, G.W.; Ram, S.; Rice, P.A. Antibody to Reduction Modifiable Protein Increases the Bacterial Burden and the Duration of Gonococcal Infection in A Mouse Model. J. Infect. Dis. 2015, 212, 311-315. [CrossRef]

117. Joiner, K.A.; Scales, R.; Warren, K.A.; Frank, M.M.; Rice, P.A. Mechanism of Action of Blocking Immunoglobulin G for Neisseria gonorrhoeae. J. Clin. Investig. 1985, 76, 1765-1772. [CrossRef]

118. Plummer, F.A.; Chubb, H.; Simonsen, J.N.; Bosire, M.; Slaney, L.; Maclean, I.; Ndinya-Achola, J.O.; Waiyaki, P.; Brunham, R.C. Antibody to Rmp (Outer Membrane Protein 3) Increases Susceptibility to Gonococcal Infection. J. Clin. Investig. 1993, 91, 339-343. [CrossRef]

119. Greenberg, I.; Diena, B.B.; Kenny, C.P.; Znamirowski, R. Preliminary Studies on the Development of A Gonococcal Vaccine. Bull. World Health Organ. 1971, 45, 531-535.

120. Greenberg, I.; Diena, B.B.; Ashton, F.A.; Wallace, R.; Kenny, C.P.; Znamirowski, R.; Ferrari, H.; Atkinson, J. Gonococcal Vaccine Studies in Inuvik. Can. J. Public Health 1974, 65, 29-33. [PubMed]

121. Greenberg, L. Field Trials of A Gonococcal Vaccine. J. Reprod. Med. 1975, 14, 34-36.

122. Tramont, E.C.; Boslego, J.W. Pilus Vaccines. Vaccine 1985, 3, 3-10. [CrossRef]

123. Boslego, J.W.; Tramont, E.C.; Chung, R.C.; McChesney, D.G.; Ciak, J.; Sadoff, J.C.; Piziak, M.V.; Brown, J.D.; Brinton, C.C., Jr.; Wood, S.W.; et al. Efficacy Trial of A Parenteral Gonococcal Pilus Vaccine in Men. Vaccine 1991, 9, 154-162. [CrossRef]

124. Rice, P.A.; Gulati, S.; McQuillen, D.P.; Ram, S. Is There Protective Immunity to Gonococcal Disease? In Proceedings of the Tenth International Pathogenic Neisseria Conference, Baltimore, MD, USA, 8-13 September 1996. 
125. Schwechheimer, C.; Kuehn, M.J. Outer-Membrane Vesicles from Gram-Negative Bacteria: Biogenesis and Functions. Nat. Rev. Microbiol. 2015, 13, 605-619. [CrossRef] [PubMed]

126. Acevedo, R.; Fernandez, S.; Zayas, C.; Acosta, A.; Sarmiento, M.; Ferro, V.; Rosenqvist, E.; Campa, C.; Cardoso, D.; Garcia, L.; et al. Bacterial Outer Membrane Vesicles and Vaccine Applications. Front. Immunol. 2014, 5, 121. [CrossRef]

127. Metzger, D.W. IL-12 as An Adjuvant for the Enhancement of Protective Humoral Immunity. Expert Rev. Vaccines 2009, 8, 515-518. [CrossRef]

128. Metzger, D.W. Interleukin-12 as An Adjuvant for Induction of Protective Antibody Responses. Cytokine 2010, 52, 102-107. [CrossRef] [PubMed]

129. Liu, Y.; Egilmez, N.K.; Russell, M.W. Enhancement of Adaptive Immunity to Neisseria gonorrhoeae by Local Intravaginal Administration of MICROENCAPSULATED interleukin 12. J. Infect. Dis. 2013, 208, 1821-1829. [CrossRef]

130. Liu, Y.; Hammer, L.A.; Liu, W.; Hobbs, M.M.; Zielke, R.A.; Sikora, A.E.; Jerse, A.E.; Egilmez, N.K.; Russell, M.W. Experimental vaccine induces Th1-driven immune responses and resistance to Neisseria gonorrhoeae infection in a murine model. Mucosal Immunol. 2017, 10, 1594-1608. [CrossRef]

131. Liu, Y.; Perez, J.; Hammer, L.A.; Gallagher, H.C.; De Jesus, M.; Egilmez, N.K.; Russell, M.W. Intravaginal Administration of Interleukin 12 during Genital Gonococcal Infection in Mice Induces Immunity to Heterologous Strains of Neisseria gonorrhoeae. mSphere 2018, 3, e00421-17. [CrossRef]

132. Gulati, S.; Zheng, B.; Reed, G.W.; Su, X.; Cox, A.D.; St. Michael, F.; Stupak, J.; Lewis, L.A.; Ram, S.; Rice, P.A. Immunization against A Saccharide Epitope Accelerates Clearance of Experimental Gonococcal Infection. PLoS Pathog. 2013, 9, e1003559. [CrossRef] [PubMed]

133. Gulati, S.; Pennington, M.W.; Czerwinski, A.; Carter, D.; Zheng, B.; Nowak, N.A.; DeOliveira, R.B.; Shaughnessy, J.; Reed, G.W.; Ram, S.; et al. Preclinical Efficacy of A Lipooligosaccharide Peptide Mimic Candidate Gonococcal Vaccine. mBio 2019, 10, e02552-19. [CrossRef] [PubMed]

134. Gulati, S.; McQuillen, D.P.; Mandrell, R.E.; Jani, D.B.; Rice, P.A. Immunogenicity of Neisseria gonorrhoeae Lipooligosaccharide Epitope 2C7, Widely Expressed In Vivo with No Immunochemical Similarity to Human Glycosphingolipids. J. Infect. Dis. 1996, 174, 1223-1237. [CrossRef] [PubMed]

135. Jerse, A.E.; Bash, M.C.; Russell, M.W. Vaccines against Gonorrhea: Current Status and Future Challenges. Vaccine 2014, 32, 1579-1587. [CrossRef] [PubMed]

136. Edwards, J.L.; Jennings, M.P.; Apicella, M.A.; Seib, K.L. Is Gonococcal Disease Preventable? The Importance of Understanding Immunity and Pathogenesis in Vaccine Development. Crit. Rev. Microbiol. 2016, 42, 928-941. [CrossRef] [PubMed]

137. Russell, M.W.; Jerse, A.E.; Gray-Owen, S.D. Progress toward A Gonococcal Vaccine: The Way Forward. Front. Immunol. 2019, 10, 2417. [CrossRef] [PubMed]

138. Arko, R.J.; Duncan, W.P.; Jerry, W.B.; Peacock, W.L.; Tomizawa, T. Immunity in Infection with Neisseria gonorrhoeae: Duration and Serological Response in the Chimpanzee. J. Infect. Dis. 1976, 133, 436-440. [CrossRef]

139. Vincent, L.R.; Jerse, A.E. Biological Feasibility and Importance of A Gonorrhea Vaccine for Global Public Health. Vaccine 2019, 37, 7419-7426. [CrossRef]

140. Hobbs, M.M.; Sparling, P.F.; Cohen, M.S.; Shafer, W.M.; Deal, C.D.; Jerse, A.E. Experimental Gonococcal Infection in Male Volunteers: Cumulative Experience with Neisseria gonorrhoeae Strains FA1090 and MS11mkC. Front. Microbiol. $2011,2,123$. [CrossRef]

141. Sierra-González, V.G. Cuban Meningococcal Vaccine VA-MENGOC-BC: 30 Years of Use and Future Potential. MEDICC Rev. 2019, 21, 19-27. [CrossRef]

142. Holst, J.; Oster, P.; Arnold, R.; Tatley, M.; Næss, L.; Aaberge, I.; Galloway, Y.; McNicholas, A.; O’Hallahan, J.; Rosenqvist, E.; et al. Vaccines against Meningococcal Serogroup B Disease Containing Outer Membrane Vesicles (OMV): Lessons from Past Programs and Implications for the Future. Hum. Vaccines Immunother. 2013, 9, 1241-1253. [CrossRef] [PubMed]

143. Gala, R.P.; Zaman, R.U.; D'Souza, M.J.; Zughaier, S.M. Novel Whole-Cell Inactivated Neisseria gonorrhoeae Microparticles as Vaccine Formulation in Microneedle-Based Transdermal Immunization. Vaccines 2018, 6, 60. [CrossRef] [PubMed]

144. Kłyż, A.; Piekarowicz, A. Phage Proteins Are Expressed on the Surface of Neisseria gonorrhoeae and Are Potential Vaccine Candidates. PLoS ONE 2018, 13, e0202437. [CrossRef]

145. Toneatto, D.; Pizza, M.; Masignani, V.; Rappuoli, R. Emerging Experience with Meningococcal Serogroup B Protein Vaccines. Expert Rev. Vaccines 2017, 16, 433-451. [CrossRef] [PubMed]

146. Harrison, O.B.; Claus, H.; Jiang, Y.; Bennett, J.S.; Bratcher, H.B.; Jolley, K.A.; Corton, C.; Care, R.; Poolman, J.T.; Zollinger, W.D.; et al. Description and Nomenclature of Neisseria meningitidis Capsule Locus. Emerg. Infect. Dis. 2013, 19, 566-573. [CrossRef]

147. Ochoa-Azze, R.F.; García-Imía, L.; Vérez-Bencomo, V. Effectiveness of A Serogroup B and C Meningococcal Vaccine Developed in Cuba. MEDICC Rev. 2018, 20, 22-29. [CrossRef]

148. Ochoa-Azze, R.F. Cross-Protection Induced by VA-MENGOC-BC ${ }^{\circledR}$ Vaccine. Hum. Vaccines Immunother. 2018, 14, 1064-1068. [CrossRef]

149. Sotolongo, F.; Campa, C.; Casanueva, V.; Fajardo, E.M.; Cuevas, I.E.; González, N. Cuban Meningococcal BC Vaccine: Experiences and Contributions from 20 Years of Application. MEDICC Rev. 2007, 9, 16-22. [CrossRef]

150. Cuello, M.; Cabrera, O.; Acevedo, R.; Nuñez, N.; del Campo, J.; Lastre, M.; Zayas, C.; González, E.; Balboa, J.; Romeu, B.; et al. Inmunización Nasal con AFCo1 Induce en Ratones Respuesta Inmune A N. gonorrhoea. Vaccimonitor 2009, 18, 78-80. 
151. Pérez, O.; del Campo, J.; Cuello, M.; González, E.; Nuñez, N.; Cabrera, O.; Llanes, R.; Acevedo, R.; Zayas, C.; Balboa, J.; et al. Mucosal Approaches in Neisseria Vaccinology. Vaccimonitor 2009, 18, 53-55.

152. Arnold, R.; Galloway, Y.; McNicholas, A.; O'Hallahan, J. Effectiveness of A Vaccination Programme for An Epidemic of Meningococcal B in New Zealand. Vaccine 2011, 29, 7100-7106. [CrossRef]

153. Paynter, J.; Goodyear-Smith, F.; Morgan, J.; Saxton, P.; Black, S.; Petousis-Harris, H. Effectiveness of A Group B Outer Membrane Vesicle Meningococcal Vaccine in Preventing Hospitalization from Gonorrhea in New Zealand: A Retrospective Cohort Study. Vaccines 2019, 7, 5. [CrossRef]

154. Pizza, M.; Bekkat-Berkani, R.; Rappuoli, R. Vaccines against Meningococcal Diseases. Microorganisms 2020, 8, 1521. [CrossRef]

155. Basta, N.E.; Mahmoud, A.A.F.; Wolfson, J.; Ploss, A.; Heller, B.L.; Hanna, S.; Johnsen, P.; Izzo, R.; Grenfell, B.T.; Findlow, J.; et al. Immunogenicity of A Meningococcal B Vaccine during A University Outbreak. N. Engl. J. Med. 2016, 375, 220-228. [CrossRef] [PubMed]

156. Lujan, E.; Winter, K.; Rovaris, J.; Liu, Q.; Granoff, D.M. Serum Bactericidal Antibody Responses of Students Immunized with A Meningococcal Serogroup B Vaccine in Response to An Outbreak on A University Campus. Clin. Infect. Dis. 2017, 65, 1112-1119. [CrossRef] [PubMed]

157. Parikh, S.R.; Andrews, N.J.; Beebeejaun, K.; Campbell, H.; Ribeiro, S.; Ward, C.; White, J.M.; Borrow, R.; Ramsay, M.E.; Ladhani, S.N. Effectiveness and Impact of A Reduced Infant Schedule of 4CMenB Vaccine against Group B Meningococcal Disease in England: A National Observational Cohort Study. Lancet 2016, 388, 2775-2782. [CrossRef]

158. Longtin, J.; Dion, R.; Simard, M.; Belinga, J.-F.B.; Longtin, Y.; Lefebvre, B.; Labbé, A.-C.; Deceuninck, G.; De Wals, P. Possible Impact of Wide-Scale Vaccination against Serogroup B Neisseria meningitidis on Gonorrhea Incidence Rates in One Region of Quebec, Canada. Open Forum Infect. Dis. 2017, 4, S734-S735. [CrossRef]

159. Semchenko, E.A.; Tan, A.; Borrow, R.; Seib, K.L. The Serogroup B Meningococcal Vaccine Bexsero ${ }^{\circledR}$ Elicits Antibodies to Neisseria gonorrhoeae. Clin. Infect. Dis. 2019, 69, 1101-1111. [CrossRef] [PubMed]

160. Australian New Zealand Clinical Trials Registry. Identifier ACTRN12619001478101. MenGO: Does the Licensed Meningococcal Vaccine Bexsero®Provide Cross-Protection against Gonorrhoea in Gay and Bisexual Men? 25 October 2019. Available online: https: / / www.anzctr.org.au/ACTRN12619001478101.aspx (accessed on 17 May 2021).

161. ClinicalTrials.gov. Identifier NCT04415424. Efficacy Study of 4CMenB (Bexsero®) to Prevent Gonorrhoea Infection in Gay and Bisexual Men (GoGoVax). 4 June 2020. Available online: https:/ / clinicaltrials.gov/ct2/show / study /NCT04415424 (accessed on 17 May 2021).

162. ClinicalTrials.gov. Identifier NCT04398849. Immunisation for Adolescents against Serious Communicable Diseases (B Part of it NT). 21 May 2020. Available online: https:/ / clinicaltrials.gov/ct2/show/study/NCT04398849 (accessed on 17 May 2021).

163. World Health Organization. Human Papillomavirus Vaccines: WHO Position Paper, May 2017-Recommendations. Vaccine 2017, 35, 5753-5755. [CrossRef] [PubMed]

164. Constable, C.; Caplan, A. Comparison of the Implementation of Human Papillomavirus and Hepatitis B Vaccination Programs in the United States: Implications for Future Vaccines. Vaccine 2020, 38, 954-962. [CrossRef] [PubMed] 